\title{
Making Sense of Life, Global Activism in the Cyberspace
}

\author{
Aide Esu \\ Department of Social Sciences and Institutions, University of Cagliari, Italy
}

Copyright $\bigcirc 2017$ by authors, all rights reserved. Authors agree that this article remains permanently open access under the terms of the Creative Commons Attribution License 4.0 International License

\begin{abstract}
Several recent works have examined the relationship between social media and social movements in the latest cycle of protest. The article examines how media activism provides a cross-fertilising communication process by shaping a cosmopolitan imagination. First the article proposes the cases of Adbuster and Avaaz, as two examples of media activism, equally engaged in changing the state of the world. The similarities and the differences between the two case studies are highlighted in order to understand how a cosmopolitan imagination, as a new challenge to the global information society, is constructed. Second, I will explore how action shapes an online community, bypassing state borders and takes on a form that shares visions, actions and strategies and develops a new common language, representing a balance between two sets of tensions: the politics of universalism versus the acknowledgement of difference and the responsibility for action.
\end{abstract}

Keywords Media Activism, Cosmopolitan Imagination, Virtual Communities, Avaaz, Adbuster

\section{Introduction}

In the recent cycle of protest, social researchers have paid great attention to social movements and social media links. The rising significance of social media mobilisation has opened new questions related to computer-mediated communication, political and social action and cast a light on the concept of cosmopolitan and cultural citizenship [1, 2, 3, 4]. Following the key paradigm of his earlier work (Communication Power), Castells depicts the movements that erupted across the Arab world and Western countries in 2011 as a clear manifestation of "mass self-communication" [2]. The brick and mortar of this wave of protest are the digital media, wikis, tweets, social networks and blogs that have been put to use in the support of the participation and transformation of new platforms that increase the "autonomy of the actor". Attention has been paid to inquiring if global activism represents a movement or not [5, 6]. My argument, based on the case of Adbuster and Avaaz that I present in this article, is that global activism creates an environment for a digital public sphere that multiplies practices, shares visions and hybridises languages, allowing its participants to move easily from different topics and issues as the result of the intersection of a networking logic and the logic of aggregation [7]. Castells [2] shows how the Jasmine Revolution that began in Tunisia in 2010 was sourced in the convergence of an active group of unemployed college graduates, in alignment with a solid culture if cyber activism and a high rate of internet connection. There is no doubt about the powerful role played by the new media in those events $[8,9,10]$. Following the idea of a connective logic of action, Bennett and Segerberg are more inclined to see the relevance of social media activism as the mirror of the growing individualisation and personalisation related to the decline of traditional parties [10]. Media activism will respond to individual organisational needs rather than acting as an active content player of social mobilisation; the logic of connective action thus pays more attention to the organisational dimension rather than the cultural transformation generated by the collective action [10]. It is in this direction that Gerbaudo and Treré [11] cast doubt on the marginalisation of a collective identity embodied in the logic of connective action by appraising the findings of different contributions to media and collective identity and emphasising the need for further research to explore how the actions of social movements are changing in the digital era. As Juris argues in his research [7], over the past two decades, the global justice movements have typified a cultural logic of networking that has easily channelled this practice to digital media. The rhizomatic revolutions, as Castells labelled Spain's anti-austerity movement, the Indignados, along with the Arab Spring movements [2], integrate the online communities, thereby empowering the offline communities and capitalising on the practices of past social movements by also embracing such participatory processes as deliberative democracy. Digital media play a crucial role, not only in terms of connective action but in appraising and sharing the knowledge of social movements by empowering the repertoire of possible actions and putting, once again, the public space at the core of visibility 
through the creation of noticeable places (Plaza del Sol, Syntagma, Zuccotti Park, Gezi Park) that become identifiable as the movement's symbol. Underscoring the identity function and symbolic places, as one of the characteristics of these movements, Castells stresses the peculiar nature of those hybrid spaces that consist of virtual and real worlds, which constitute a gathering of the online and the offline communities in physical and symbolic squares. The online and offline communities pave the way to magnify information sharing views, practices and strategies. The Occupy Movement was born from this logic of convergence of networking and aggregation. One of the two case studies we present in this paper, Adbuster, provides evidence of the merging of the first and the second generation of digital democracy [12]. Born in 1989 as one of a series of online campaigns of critical consumption, in June 2011 Adbuster played a pivotal role in diffusing the hashtag \#OccupyWallStreet. This call for action capitalised on past activities, such as campaigns and networking platforms set up by Adbuster and the World Social Forums. It also appraised the repertoire of action and communication forms of past social movements and civil rights disobedience, to experiment with direct democracy, thereby attesting that past social action knowledge does not end when the movement comes to an end [13].

In this paper I discuss the case of Adbuster and Avaaz, as two examples of the first and second generations of Internet activism. Adbuster and Avaaz might be defined as forums for media activism, which are equally engaged in changing the state of the world. The discussion of those two cases aims to understand how media activism creates a challenging environment for a cosmopolitan imagination in the global information society and how this cosmopolitan imagination contributes to the symbolic and cultural dimension of social media activism. I explore how a cross-fertilisation of language and practices expands the global interaction of the online communities through the bypassing of state borders and the sharing of visions, actions and strategies, which can lead to the development of new common languages.

The paper is organised as follows. In the first section, I present Adbuster and Avaaz, describing the groups' origins, philosophies, modus operandi and repertoire of actions. In the second section, I reflect on media activism and the public sphere focusing on how rising media groups in the information society have changed the way democracy works and how this opens new questions in the social movement theory. In the third section, in light of the previous paragraph, attention is paid to the cross-fertilisation of languages, values and practices of Adbuster and Avaaz on media activism. The last section brings into discussion the concepts of cultural citizenship, cosmopolitanism and cosmopolitan imagination in order to understand if the two case studies might be considered as emblematic expressions of an emergent social phenomenon of our late modernity.

\section{Adbuster and Avaaz: Who are they?}

The Adbuster Media Foundation has been active since 1989 when it began a series of campaigns promoting anti-consumerism practices. Based in Vancouver, Canada, AMF was founded by the Danish-born activist Kalle Lasn. Currently, the organisation publishes a quarterly magazine, entitled Adbusters, which reaches approximately 120,000 readers and has the appearance of an elite design magazine. The publication's content is highly premised on irony and parody and is greatly critical of mainstream advertising, consumer products and a consumerist lifestyle. Salient attention is paid to the commentaries of scholars, writers and intellectuals that contribute to critical thinking about the consumption society, which draw a distinct profile of what they have referred to as the consumerism environment.

Adbuster publishes its own satirical versions of real print promotions, with the intent of using humour to expose the negative social, psychological and environmental impacts of the products they depict. Their work has been embraced by organisations like Friends of the Earth and Greenpeace and has been featured in hundreds of alternative and mainstream newspapers, magazines and television and radio shows around the world. Adbusters refers to its specific style of political expression as "culture jamming", a term coined in 1985 by a San Francisco-based music group called Negativland [14]. Culture jamming started as a subversive underground culture critique movement and a form of language détournement, which adapts the language of advertising in provocative ways, through the use of what is called subvertisement. It includes various forms of media sabotage such as media hoaxing, audio agitprop, billboard-banditry and guerrilla semiotics. The market-oriented boycotts target big companies like Philip Morris for an anti-smoking campaign or Nike for an anti-child labor campaign, or the campaign aimed at Starbucks, "What would Jesus buy?", as raised by the performance artist and activist Reverend Billy. The so-called "un-commercials" that appear in Adbusters are creative caricatures of familiar advertisements and, as such, are paradigmatic examples of culture jamming. This mode of resistance has begun to transcend the clever lampooning of cultural symbols to include vandalising billboards and defacing other promotional media. The use of art as a form of protest distinguishes the campaign "Reclaiming Urban Space" (2000), which consists of the diffusion of gigantic billboard along the urban areas edited by the Billboard Liberation Front and anti-consumerism statements developed by the campaign "Creative Resistance".

Culture jamming is exemplified by the Adbuster label, being extensively adopted for civil disobedience and other provocative means to reclaim certain "strategic spaces" that have been appropriated for commercial purposes. The specific spaces to which culture-jamming techniques are applied can be physical places, such as parks, promenades and highways, as well as more subtly psychological and 
cultural spheres. The repertoire of actions includes practices of civil disobedience, boycott campaigns and other modes of resistance by promoting successful world campaigns like Buy Nothing Day and the Digital detox challenge. Looking at culture jamming from a sociological perspective, Carducci underlines the attempt to raise an ad hoc form of social marketing confronting the authority of corporate representation [15]. The counter-hegemonic discourse by which Adbusters is, in Rumbo's view, a clear-cut attempt to develop a counterhegemonic discourse following Gramscian organic intellectual theory $[16,134]$.

Following the outbreak of the Arab Spring protests, the practice of culture jamming moved to a more politically framed action. In February 2011, the editors of AMF, Kalle Lans and Micha White, advocated for the spreading of Egypt's Tahir Square protest to the West: "If we want to spark a popular uprising in the West - like a million man march on Wall Street - then let's get organised, let's strategise, let's think things through". ${ }^{1}$ They championed the protest via their mail list, and in June they registered the OccupyWallStreet.org web site and came up with the idea to occupy a public space, announcing the public gathering for September $17^{\text {th }}$.

The call to occupy Wall Street wasn't an endorsement but a move into a more political territory in keeping with the original ethos and inviting people to "Bring signs, flowers, food and a revolutionary mood... and a commitment to absolute nonviolence in the Gandhian tradition". 2

Avaaz was born as a global civic movement, an international civic organisation established in 2007, co-founded by Res Publica, a global civic advocacy group and non-profit organisation, and MoveOn, the American non-profit progressive advocacy group and political action committee. The organisation was also supported by the Service Employees International Union. The organisation operates in fifteen languages and claims, at the moment we write, more than 41 million members worldwide. ${ }^{3}$ Their mission is to organise and empower citizens around the globe to minimise the world power gap by raising awareness of global, regional and national issues from corruption to poverty, from global warming to human rights violation and pressing the local, national and international powers to enact change. They declare that the "purpose (is) create(s) 21 st century movements. We look for ways that movements can help solve major global problems. To do this, we work with some of the most exciting players in the new green and social economy to help them get to scale faster and some of the world's biggest brands to mobilize their consumers for significant social impact". ${ }^{4}$

A small team of global campaigners serves the Avaaz community, working from Switzerland, Brazil, the United
States, Argentina and the United Kingdom. They identify and develop opportunities for members to take action. They also rely on teams of expert advisors to help develop new campaigns, and, often, volunteer members work with the team on specific projects. They communicate with members via email, employing campaign tactics that include online public petitions, videos and email-your-leader tools. An annual web-poll is organised in order to develop campaigns and set priorities.

Avaaz empowers its members to take action on pressing issues of international concern, from global poverty to Middle East crises and climate change. Appealing to the rising ethic of global interdependence, they offer the platform like a technological megaphone to organise thousands of individual efforts - a campaign may be organised by an individual or a small group - to be rapidly combined into a powerful collective force. In 7 years, Avaaz has initiated more than 180,000 actions, with 63 successful campaigns around the world, grown to include 41 million members from 194 countries and become the largest global web movement in history. ${ }^{5}$ The use of a wide range of social networks that include Facebook, MySpace, YouTube, Flickr and Twitter improve the high-speed mobilisation through the designed website "that allows numerous participants to undertake easy, brief and small actions" [17] and have a strong influence on the potentialities of mobilisation. The Avaaz platform encourages self-mobilisation by offering the opportunity to take action in promoting a campaign on issues that can be local, national or larger. Individual agency might be limited to a narrow dimension and activate a collective action, without being affected in terms of political significance. The online community uses the Avaaz network as a megaphone to promote the chosen action to a broad range of public concern about it. The agenda is fixed through a bottom-up approach by establishing the overall priorities through members' polls; campaign ideas are tested weekly to 10.000 members, suggesting ideas that are taken up in order to affect the broader community. Avaaz is something more than a simple megaphone; when a campaign idea is established, the staff work with partners and experts to develop effective, member-driven strategies. The connection of local concerns to global problems enables Avaaz to call attention to international issues like peace in the Middle East, the Iraqi war and provide support to the Arab uprising by offering training to citizen journalists and technological support, while contributing through fundraising efforts to such actions as the Occupy movement.

5 Avaaz promoted growing number of petitions: peace in Middle East, food safety, outcry for truth (swine flu) environment protection, torture, food aid, fundraising (rebuild Haiti, flood in Pakistan), homophobia, etc. See http://www.avaaz.org
$1 \mathrm{https}: / /$ www.adbusters.org/blogs/adbusters-blog/million-man-march-wallstreet.html

2 https://www.adbusters.org/blogs/adbusters-blog/occupywallstreet.html

3 Avaaz web site, www.avaaz.com

4 http://www.avaaz.org/en/about.php 


\section{Media Activism and Public Sphere}

A flourishing number of studies have called attention to the changes that have taken place in the role played by the net in the public sphere $[18,6,19]$. Dahlgren [20] in particular highlights how the communication spaces are aligned on three levels: the structural level, where economic, legal and organisational dimensions intersect; the representative scale (media outputs and recipients); and the interaction level. Regarding the last one, the author recalls that, according to Habermas and Dewey, the public, as the results of the discursive interactional process, continues to be well grounded. Nevertheless, acting in the net, the atomised individuals are not strictly part of the public, being limited to the media activity in the sphere of their personal experience [20]. As civic mobilisation bloomed in the past decade, especially the development of horizontal communication, new technologies have been changing the way democracy works. Media activism grows as far as the awareness of the significance of the interconnection and the effects of the global crisis at the local level extends. Questions arise about the blurring of the territorial exclusivity of state sovereignty delimiting the public sphere and the meaning of the "transnational public sphere" [21, 77]. Globalisation, as Saskia Sassen [22] says, unfolds micro processes that de-nationalise what historically has been designated as national: territory, authority and rights. The rise of global institutions, absorbing part of the national state functionality, creates global socio-political spaces in which digital practices and connections come to play a new and important part, thereby making visible a transnational publicity. In the enlarged political space, new players, like international bodies, come to take decisions on behalf of the nation states. The attention of media activists is focused in this direction, moving from internal to international issues, or to linked issues, especially on financial matters. Corporations and the international economic and financial super powers are identified as the new opponent [4]. New advocacy groups are promoted targeting the World Trade Organization (WTO), International Monetary Fund (IMF) and the World Bank, as responsible for the neoliberal turn. Tarrow offers a broader definition of internationalisation that interrelates three levels: the increasing density of state relations, a vertical level with subnational, national and international interdependencies, and a formal and informal level of transnational relations that pave the way for networks of state and non-state actors $[4,8]$. In this new frame, the political opportunities bypass state borders and the actions of social movements enter in the dimension of social media activism. The networking action of those movements uses computer-mediated communication as an alternative to face-to-face organisations. In Tarrows' view [23], advocacy networks are a connecting structure rather than a social network. Since the end of the 90s, a growing number of social scientists have paid attention to this turn, wondering if this change represents a new paradigm in social movement theory or if the use of the Internet designates a simple instrumental or organisational tool. Diani, recalling his definition of social movements as "networks of informal relationships between a multiplicity of individuals and organizations, who share a distinctive collective identity, and mobilize resources on conflictual issues" [24, 287] recognises that computer-mediated communication has a significant impact on political activism, encouraging polyadic instead of dyadic relationships and facilitating communication.

Criticism is associated with how the idea of community evolves in the net, particularly on the emphasis given to participants' behaviour related to the hiding of personal identity in discussion groups. Bakardjieva observes that a "situated rationality" appears to be a way of belonging to several communities in the pursuit of single needs [25] and developing a virtual togetherness in everyday life that dichotomises the real and the virtual, the public and the private [26]. When the online and offline spheres are linked to each other, the civic participation changes, and Goodsell and Williamson argue that computer-mediated communication creates the possibility for the formation of online (virtual) communities separate from offline communities, "but the interaction between two such communities - one online and one offline - creates a new model for community, a hybrid community, with much potential for the success of both online and offline interaction" [27, 251]. The authors, looking at the theory of new social movements and media activism, call attention to the different focus of the online communities; rather than create a new collective identity, the goal is to build a politics of connection rather than one of mobilisation [26]. However, Gladwell [28] and Morozov [29] warn about the risks of "clicktivism" or "slacktivism" as ephemeral and superficial actions that make participants feel good about their inner voices but have no real impact on political life. The apathetic use of social media as an effortless action that sometimes supplies a more demanding political participation also highlights the weak distinction between private and public political actions. This controversial debate over the effects of digital engagement is addressed by a few research studies. A meta-data study on 38 cases with 166 significant effects on engagement shows that access to different sets of political information can strengthen civic life and reduce the cost of participation [30, 205]. The study calls attention to the assessment of the risks and dangers posed by the Internet, particularly the naïve cyber-utopianism of the emancipatory nature of online communication. Morozov's critique addresses the early theorists that failed to take the State out of the picture and questions how non-democratic systems like Iran, Belarus and Turkey (among others) mastered the use of the Internet to empower surveillance, and demonstrates that the Internet "empowers the strong and disempowers the weak" [29, $\mathrm{XV}]$.

The contemporary literature on civil society has 
highlighted how the actions of resistance and radicalism imply a certain level of emancipatory and democratic aspirations of the public sphere [31]. The global movements for the rights of communication act on several fronts, opening new questions related to their practices; they are players who adopt classical repertoires of protest and civil disobedience [4], but, in the information society, the enlargement of public space in the electronic sphere opens a new transnational space. As long as the actions of civic order proliferate in the network, the Internet increases the capacity of horizontal communication. Moreover, some ambiguities emerged concerning the nature of the episodic public sphere. The action transcends the predefined boundaries; the emergent global context of political issues shows the capacity of civil society to move beyond the predictable state borders $[31,32]$. The definition of the public sphere still remains a blurring space; to the degree that media activism is a diverse collective action being more related to a strategic interaction [33, 89]. Nancy Fraser, questioning the transnationalising of the public sphere, recognises how hard it is to associate the communicative power to the discursive space without a Westphalian political imaginary. In the deterritorialised cyberspace, where the use of English as lingua franca raises the question of how those groups create their public sphere going beyond their demonstrations, even the linguistic communities compromise their legitimacy and efficacy $[21,91]$.

\section{4. from Adbuster to Avaaz, the Cross-fertilisation of Media Activism}

Downing (2008) observes that the majority analyses of social change in media studies focus on the development of communication, cultural studies and political communication. In the rich panorama of media activism, Adbuster and Avaaz have a long-standing reputation, shaping a collective identity engaged in transforming the balance of power through empowering social actors.

Carroll and Hackett observed that culture jamming, media monitoring and internet activism have become a common repertoire of action for different movements [37, 89]. The cross-fertilisation of languages, values and practices has empowered the reflexivity of social movements around the globe. The Adbuster counter-hegemonic example of using the publication's technique of "bustering" consumerist icons has fertilised several Avaaz world campaigns, like the climate wake-up call.

It is widely recognised that cultural jamming has pioneered the practice of the bustering of consumerism, thereby creating the ecology of communication that is essential to many forms of media activism $[34,16,36]$. The various engagements of Avaaz and Adbuster to change the state of the world are punctuated by a common repertoire of action in spite of relevant distinctions in social and political organisation. As an organisation, Adbusters is created in the context of a postmodern critique of consumption society as an entity that "can be grouped into two main themes- the colonization of spaces by marketing and mass media technologies and the degradation of natural environments resulting from rising global economic growth and concomitant human consumption" $[18,138]$. By following the course of advocating for the Occupy mobilisation, Adbuster has shifted from cultural criticism to a radical political discourse. Nevertheless, the culture jamming message is mixed with a mainstreaming repertoire of new social movements like boycotts, acts of civil disobedience, street rallies and so on. Avaaz, which acts "predominantly as a virtual organization" $[18,30]$, comes from the world of international politics, implementing such previous online communities as the Res-Publica Group, which is committed to the promotion of "good governance and deliberative democracy", and Move-on, which is dedicated to developing a political progressive globalism in politics. Kavada observes that the organisation is designed to be a form of activism for busy people, in the hope that social media platforms may stimulate mobilisation and sharing of values and beliefs.

In his first essay on network society, Castells [37] emphasises the innovative nature played by open links, which in his view are instrumental to the immanent global and cosmopolitan dimension. Being active in the net means to contribute to the democratisation of communication, through advocating the universal right to communicate. In the practices of Adbuster and Avaaz, online and offline communities are not separate worlds. Online activities might predominate, but like other groups of the network society, steady relations link them. Petitions, direct mobilisations and local/global mobilisations are accompanied or followed by the offline communities, reinforcing the two spheres of action, creating "a new model for community, a hybrid community, with much potential for the success of both online and offline interaction" [27, 251]. Campaigns like Buy Nothing Day (Adbuster) or the Wakeup call for climate change (Avaaz) have revealed how joint actions develop a dialogue between both communities that have the potential to change the civic culture. By spreading the hashtag OccupyWallStreet, Adbuster capitalises on the fact that the Internet is not a single community and takes advantage of the networking of each member in the form of a "home-made algorithm" of data-mining, connecting the online and offline groups, creating a new community across the two spheres. Adbuster and Avaaz, following different paths, design hybrid communities within which activists hold multiple identities giving form to Diani's [24] relational perspective of media activism. The media activism of Avaaz is closer to a politics of connection rather than that of constructing a collective identity among the group's members. The campaign to influence the Climate Change Conference in Copenhagen is a noticeable example of global offline-online community 
action. A worldwide protest of local groups, united by the need to call the attention of world leaders to the top-priority actions necessary to save the environment, has been mixing traditional social protest practices (rallies in public squares), the new forms of political-cultural protest (flash mobs and Adbuster style posters) and media activism tools (mail bombing of decision makers). This example converges with Carrol and Hackett's view on media activism as a type of mobilisation that brings together several practices, embedding other activist causes, in a "constantly transgressing political boundaries, so instead of interiorized the action system they exteriorized multiplying with other communities" [33, 100]. Avaaz members are likely close to the profile design by Tarrow in managing transnational mobilisation and local mobilisation. They "utilize their domestic resources and opportunities to move in and out of international institutions, processes, and alliances" [4, 28] and reinforce Papacharissi's view of online public spaces as a hybrid model where consumerism and civic rhetoric converge [38, 232].

\section{Media Activism and Cosmopolitan Imagination}

What cultural changes has media activism created? What sociological significance do we find in the action of signing a petition in New York to save Maasai Land, or living in Bombay and signing a petition to pressure Israeli government to stop building settlements in the West Bank, or organising a flash mob in Latvia to call attention to consumerism during Buy Nothing Day in synchronisation with thousands of people in Alberta, Milan, London, Buenos Aires? What do these people have in common? What do they share? They use the same tools of media activism to do something that has no direct effect on their everyday life, so why do they act in this way? Is a new form of citizenship rising?

Rick Patel, who inspired Avaaz.org, argued that while working at the top level of the United Nations he understood how weak was the capability of this institution to create real change, and how far the decision power was from people' needs. The Avaaz founders declared themselves to be engaged in expanding the frameworks of people's common understanding by adopting the collective empowerment to move in the direction of a new world citizenship. Acting as rooted cosmopolitans, the virtual community members fitted Tarrow's profile as "individuals and groups who mobilize domestic and international resources and opportunities to advance claims on behalf of external actors, against external opponents, or in favour of goals they hold in common with transnational allies" [4, 28].

Castells, looking at media activism as a pillar of mobilisation in the information age, emphasises the need for reconsidering the concepts of citizenship, cosmopolitanism and social imagination in order to make sense of the ongoing social transformations. It is Castells' belief that the Internet and mobile phones are not simple technological devices, but rather open the door for "organizational forms, cultural expression and specific platforms for political autonomy" $[2,103]$. The social actors' autonomy is Castells' interpretation of the recent cycle of protest, which represents a new strength for democracy and a revitalising source for civil society, particularly in the Arab world, as the Arab Spring has largely demonstrated. This form of networking, in the digital age, goes far beyond the mainstreaming representation of the sharing and disseminating of information; it stands on a platform of knowledge, learning and creation. The Avaaz training for citizen journalism during the Arab Spring or the artistic political creativity of the many vlogs of the Arab protesters confirm the dissemination of the net-philosophy, practices and new forms of expression that have enriched the performativity of social movements. The power of images to bring the emotions of far-distant observers up close to an event have "created a virtual environment of art and meaning on which activists of the movement could rely to connect with the youth population at large, thus changing culture as a tool of changing politics" [2, 107].

An inspiring debate about the concept of cosmopolitanism has arisen in the social sciences, the relevant changes emerged in the social order inspired at the core of sociology [39, 40, 41, 42, 43, 44] a discussion, which, since then, has been restricted to philosophy and political science. Delanty, reviewing this perspective, considers cosmopolitanism as the voicing of multiple ways in which the social world is shaped by different modernities $[41,27]$. Indeed, cultural rights turn up in late modernity as an inclusive conception of the recognition of minorities' rights, consumers' rights and environmental rights (from natural resources protection to food safety and to land and crops' rights). The formation of an emergent reality of growing social mobility and cultural pluralisation being created by international migration, ethnic multiculturalism and multi-location of refugees has enlarged the space of the cosmopolitan citizen while the relevance of territory has decreased. This process is occurring in a context of risk and uncertainty $[41,36]$, which includes millions of precarious lives that are engendered by natural and environmental disasters, public health emergencies, ethnic conflicts and poverty. The "dark side" of cosmopolitanism is revealed by the ways governmentality undertakes the control of people's mobility. As far as the decrease in importance of territory goes, nations from Europe to the United States, and, more recently, Indian Ocean nations, are facing a growing process of governmentality to manage population flows in a blurring of sovereign powers. In this sense cosmopolitanism is more and more "concerned with intermixing and the ethical relations between the self and the other, but seeks an institutional and political grounding in the context of shared global problems" [44, 332]. Within the dynamics of casting 
this social world, Delanty (2006) considers the manifestation of a global public more relevant than a global public sphere.

Scholars of cosmopolitanism discern in the concept of a cultural citizenship a design for an ethics grounded in a "cosmopolitan imagination" as a new challenge for the global information society. This refers to the reality of a larger social world that opens the space to a cosmopolitan imagination in which social actors define themselves through "new relations between self, other and the world" $[40,26]$. The roots of transnational cosmopolitanism link the local and the global, where acting in the global network transcends space and compresses time and brings out new players and new relationships within a "transborder" space that enriches the traditional forms of social life and politics [45]. The action is balanced between two sets of tensions: the politics of universalism versus the acknowledgement of difference, and the contradiction between pleasure and responsibility. If cosmopolitanism is a dynamic relation between the local and the global that engenders a process of self-transformation shaping new spaces of discourse and resistance to globalisation and nationalism, then the two case-studies presented in the above pages raise questions related to how the cosmopolitan subjectivity shapes a new identity.

How does the way in which the "citizen of the world" endeavours to see and embrace the "other", define his or her identity? The self-transformation appears to go in the direction suggested by Melucci when he emphasises the claim made by social actors to make their "autonomy in making sense of their lives" [46, 41]. This insight is useful when looking for the answer in the direction of how people construct the action and the immanent process of interaction. Internet activism, through a mix of individual and collective action, linking global and local issues in a cross-fertilising communication environment empowers social responsiveness. This form of openness towards others, cast public solidarity, commitment to justice and distribution of symbolic resources [47], and upholds the ethic of citizenship based on cosmopolitan imagination. Cosmopolitan citizenship shifts the attention to collective experiences, learning processes and discourses of empowerment, participation in the political community, accordingly a way of crafting personal biographies and narratives by controlling the flow of information and cultural processes that result from it. Connectivity multiplies social worlds, imaginations and perceptions. There is little research on cross-national comparisons of Internet use. The most recent work in this area focuses on the Internet's ability to increase democracy through connectivity, looking specifically at cosmopolitan orientation toward other cultures and interest in foreign cultures [48]. Verboord's study examined the Eurobarometer data from 29 European Union countries, analysing consumption-based cosmopolitanism and distinguishing two indicators: interest in concrete cultural products and cosmopolitan orientations (beliefs in cosmopolitanism, tolerance and identification beyond the state). The results show that connectivity and openness are associated with sociopolitical values and orientations, as well as interest in foreign cultural expressions (e.g. cinema or books).

To explain the new sense of cosmopolitan citizenship Delanty recalls Honneth's conception of solidarity "as a moral feeling of indignation against oppression and disrespect" $[40,105]$. In this context, indignation appears to be the predominant reaction to inequality. Ten years of Avaaz mobilization have revealed new challenges for the global information society through a wide spectrum of actions. These range from environmental actions, such as banning glyphosate use in agriculture or the massive 2015 mobilization on climate change supported by the United Nations Secretary General; to technological actions, such as collecting three million petition signatures to preserve a free and open Internet for all; to humanitarian actions, such as rescuing refugees and collecting millions in aid to save and rebuild lives after natural disasters in Burma, Pakistan, Nepal and Haiti; to political actions, such as organizing petitions against corruption in Brazil. The overall statistics eloquently testify to the worldwide idea of cosmopolitanism, with Avaaz claiming more than 43 million members, $301,820,217$ actions and 2,792 campaigns ${ }^{6}$. Avaaz harnesses the connectivity culture that was previously spread by Adubuster's successful anti-consumerism campaigns and the Occupy movement. Avaaz mixes connectivity with the traditional repertoire of action of social movements by putting together online petitions and mail bombings, pressuring decision makers and organizing gatherings and rallies.

By gathering in assemblies, people make public their personal stories, embodying Melucci's definition of social actor autonomy. The "making sense of their lives" is performed in streets, squares and in the cyberspace as forms of plural performativity. One has one's own story and claim, but it is linked with the stories and claims of others, and the collective demand that emerges from those singular histories, becomes something plural [46, 157]. Avaaz anticipated the meaning of this collective action by calling for a cosmopolitan solidarity, not in the sense of humanitarian aid, but in the construction of a new responsiveness by organising "multiple networks of associations and individuals" and calling for a moral relationship and interaction with the "other".

The dynamics of the cosmopolitan imagination reveals a process of on-going construction, although with speeding ups and quick declines of self-constitution. It is through looking in this direction that Delanty $[41,40]$ reassesses Alain Touraine's notion of a self-defining society, as the agency of social actors to raise a transformative vision, in order to create a cosmopolitan imagined society. The lesson

6 http://www.avaaz.org/en/about.php last access February 2th 2017 
we have learned from the agency of Adbuster and Avaaz, which we have discussed in this paper, goes in this direction. Their mobilisation practices are addressed to global actors in the hope of shaping a new social world able to harmonise multiple belongings. Members of Adbuster and Avaaz belong to this emerging community of people searching for a flexible identity [49] where the local and the global might converge in a borderless society. The acceptance of cultural hybridisation opens the doors to different cultures and religions looking for a new social imaginary to be built on a different common knowledge, one based on diversity. Nevertheless, they are not so naïve as to believe in one simple world; they are truly aware that the flexible subjectivity might embody inherent conflicts and hostilities.

\section{REFERENCES}

[1] Diani M. McAdam D. (eds.) Social Movements and Networks: Relational Approaches to Collective action. New York: Oxford University Press, 2003.

[2] Castells M. Networks of Outrage and Hope: Social Movements in the Internet Age. Cambridge, London, Polity Press, 2012.

[3] Stevenson, N. (Eds.) Culture and Citizenship. Sage: London, 2001.

[4] Tarrow S. The New Transnational Activism, Cambridge: Cambridge University Press 2005.

[5] Tilly C., Tarrow S. Contentious Politics, Boulder, CO: Paradigm Publishers, 2005.

[6] Bennett W.L., Segerberg A. The logic of connective action: Digital media and the personalization of contentious politics Information, Communication \& Society, 15(5): 739-768, 2012.

[7] Juris J. S. Reflections on \#Occupy Everywhere: Social media, public space, and emerging logics of aggregation. American Ethnologist, vol 39(2), 259-279, 2012.

[8] Starbird K., Palen L. How will the revolution be retweeted? Information diffusion and the 2011 Egyptian uprising. Proceedings of the ACM 2012 conference on computer-supported cooperative work. New York, NY: ACM, pp. 7-16, 2012.

[9] Tufecki Z., Wilson Social media and the decision to participate in political protest: Observations from Tahir Square. Journal of Communication, 62(2), 363-379, 2012.

[10] Bennett W.L. New Media power: The Internet and global activism. In: Couldry N, Currans J (ds.), Contesting Media Power Lanham, MD: Rowman \& Littlefield, pp. 17-37, 2003.

[11] Gerbaudo P., Treré, E. In search of the "we" of social media activism: introduction to social media activism: introduction to the special issue on social media and protest identities. Information, Communication \& Society, 18 (8), 856-871, 2015.

[12] Loader B.D., Mercea, D. Networking Democracy? Social media innovations in participatory politics, Information, Communication \& Society. vol 14(6), pp. 757-769, 2011.

[13] Calhoun C. Occupy Wall Street in perspective. The British Journal of Sociology, vol. 64(1): pp. 26-38, 2013.

[14] Lasn K. Culture Jam: How to Reverse America's Suicidal Consumer Binge and Why We Must. New York: HarperCollins, 1999.

[15] Carducci V. Culture Jamming: A Sociological Perspective. Journal of Consumer Culture 6(1): 116-138, 2006.

[16] Rumbo J. D. Consumer Resistance in a World of Advertising Clutter: The Case of Adbuster, Psychology \& Marketing 19(2): pp.127-148. 2002

[17] Kavada A. Engagement, Bonding, and Identity across Multiple Platforms: Avaaz on Facebook, YouTube, and MySpace. MedieKultur Journal of media and communication, 52, 28-48, 2012.

[18] Cammaerts B. Van Audenhove L. ICT-usage among transnational social movements in the networked society: to organise, to mediate, and to influence, Amsterdam: ASCOR University of Amsterdam, 2000.

[19] Dahlgren P. Media, citizens and civic culture. In: Gurevitch M, Curran J (eds). Mass Media and Society ( $3^{\text {rd }}$ ed.), London: Edward Arnold, pp. 310-328, 2000.

[20] Dahlgren P. The Internet, Public Sphere, and Political Communication: Dispersion and Deliberation. Political Communication (22):147-162, 2005.

[21] Fraser N. Scales of Justice. Reimagining Political Space in a Globalizing World. New York: Columbia University Press, 2009.

[22] Sassen S. Territory, Authority, Rights: From Medieval to Global Assemblages, Princeton: Princeton University Press, 2006.

[23] Tarrow S. Power in Movement: Social Movements, Collective Action and Politics ( $2^{\text {nd }}$ Edn.). New York/Cambridge: Cambridge University Press, 1998.

[24] Diani M. Social movement networks virtual and real. Information, Communication \& Society, 3 (3): 386-401, 2000.

[25] Bakardjieva M. The Internet in Everyday Life. London: Sage Publications, 2005.

[26] Bakardjieva M. Virtual Togetherness: An Everyday-life Perspective. Media Culture Society vol 25 (3): 291-31, 2003.

[27] Goodsell T. L., Williamson O. The Case of the Brick Huggers: The Practice of an Online Community. City \& Community, vol (7) 3, pages 251-271, 2008.

[28] Gladwell M. Small Change: why the revolution will not be twitted. The New Yorker, 2010/10/04

[29] Morozov E. The Net Delusion. The Dark side of Internet Freedom. New York: Public Affairs, 2011.

[30] Boulianne S. Does Internet Use Affect Engagement? A Meta-Analysis of Research. Political Communication, 26:2, 193-211.

[31] Calabrese A. The Promise of Civil Society: A Global 
Movement for Communication Rights. Continuum, 18 (3) (September 1): 317-329, 2004.

[32] Stevenson, N. Cultural Citizenship in the 'Cultural' Society: A Cosmopolitan Approach. In Citizenship Studies, Volume 7, Number 3, September, 331-348(18), 2003.

[33] Carroll W.K. Hackett R.A. Democratic Media Activism through the Lens of Social Movement Theory. Media, Culture \& Society doi:10.1177/0163443706059289, 2006.

[34] Harold C. Pranking rhetoric: "culture jamming" as media activism. Critical Studies in Media and Communication, (21), 3, 189-211, 2004.

[35] Rumbo J. D. Consumer Resistance in a World of Advertising Clutter: The Case of Adbusters. Psychology \& Marketing 19 (2): 127-148, 2002.

[36] Wettergren A., Fun and Laughter: Culture Jamming and the Emotional Regime of Late Capitalism, Social Movements Studies, vol 8, (1), 1-15, 2009.

[37] Castells M. The Rise of the Network State. Vol. 1. The Information Age. Oxford: Blackwell, 1996.

[38] Papacharissi Z. The virtual sphere 2.0. In: Chadwick A, Howard P N (eds.). Routledge Handbook of Internet Politics. New York: Routledge. 230-244, 2009.

[39] Beck U. The Cosmopolitan Outlook. Cambridge, London: Polity Press, 2006.

[40] Delanty G. Cosmopolitan Imagination: The Renewal of Critical Social Theory. Cambridge: Cambridge University Press, 2009.
[41] Delanty G. The cosmopolitan imagination: critical cosmopolitanism and social theory. The British Journal of Sociology, vol. 57(1), 25-47, 2006.

[42] Kögler H.H. Constructing a Cosmopolitan Public Sphere: Hermeneutic Capabilities and Universal Values. European Journal of Social 8(4), 297-320, 2005.

[43] Calhoun C. Belonging in the Cosmopolitan Imaginary. Ethnicities 3(4): 531-53, 2003.

[44] Stevenson, N. Cosmopolitan Education and Cultural Citizenship: A Critical European Perspective. Cultural Sociology. doi:10.1177/1749975511401281, 2011.

[45] Katzenstein P.J. A World of Regions: Asia and Europe in the American Imperium. Cornell: Cornell University Press, 2005.

[46] Melucci A. The Process of Collective Identity. In: Johnston H \& Klandermans B (eds.). Social Movements and Culture, University of Minnesota Press, Minneapolis, pp. 41-64, 1995.

[47] Butler J. Athanasiou A. Dispossession: The Performative in the Political. Cambridge, London: Polity Press, 2013.

[48] Verboord M. Internet Usage and cosmopolitanism in Europe: a multilevel analysis. Information Communication \& Society, 20:3, pp.460-481, 2017.

[49] Ong A. Flexible Citizenship: The Cultural Logics of Transnationality. Durham: Duke University Press, 1999. 